\title{
NADP-dependent enzymes are involved in response to salt and hypoosmotic stress in cucumber plants
}

\author{
Veronika Hýsková1, Veronika Plisková1, Václav Červený ${ }^{2}$ and Helena Ryšlavá ${ }^{1}$ \\ ${ }^{1}$ Department of Biochemistry, Faculty of Science, Charles University, Hlavova 2030, Prague 2, 128 43, Czech Republic \\ ${ }^{2}$ Department of Analytical Chemistry, Faculty of Science, Charles University, Hlavova 2030, Prague 2, 128 43, Czech Republic
}

\begin{abstract}
Salt stress is one of the most damaging plant stressors, whereas hypoosmotic stress is not considered to be a dangerous type of stress in plants and has been less extensively studied. This study was performed to compare the metabolism of cucumber plants grown in soil with plants transferred to distilled water and to a $100 \mathrm{mM} \mathrm{NaCl}$ solution. Even though hypoosmotic stress caused by distilled water did not cause such significant changes in the relative water content, $\mathrm{Na}^{+} / \mathrm{K}^{+}$ratio and Rubisco content as those caused by salt stress, it was accompanied by more pronounced changes in the specific activities of NADP-dependent enzymes. After 3 days, the specific activities of NADP-isocitrate dehydrogenase, glucose-6-phosphate dehydrogenase, NADP-malic enzyme and non-phosphorylating glyceraldehyde3 -phosphate dehydrogenase in leaves were highest under hypoosmotic stress, and lowest in plants grown in soil. In roots, salt stress caused a decrease in the specific activities of major NADP-enzymes. However, at the beginning of salt stress, NADP-galactose-1-dehydrogenase and ribose-1-dehydrogenase were involved in a plant defense response in both roots and leaves. Therefore, the enhanced demands of NADPH in stress can be replenished by a wide range of NADP-dependent enzymes.
\end{abstract}

Key words: Cucumis sativa L. - Hypoosmotic stress - NADP-dependent enzymes - NADPH Salt stress

Abbreviations: AAS, atomic absorption spectrometry; AES, atomic emission spectrometry; DH, dehydrogenase; G6PDH, glucose-6-phosphate dehydrogenase; HSP, heat shock protein; NADPICDH, NADP-isocitrate dehydrogenase; NADP-ME, NADP-dependent malic enzyme; NP-GAPDH, non-phosphorylating glyceraldehyde-phosphate dehydrogenase; PVP, poly(vinylpolypyrrolidone); ROS, reactive oxygen species; Rubisco, ribulose-1,5-bisphosphate carboxylase/oxygenase; SDH, shikimate dehydrogenase.

\section{Introduction}

Whereas hyperosmotic stress caused by high salt concentration (mostly $\mathrm{Na}^{+}$and $\mathrm{Cl}^{-}$and also other ions such as $\mathrm{Ca}^{2+}, \mathrm{K}^{+}, \mathrm{HCO}_{3}{ }^{-}, \mathrm{CO}_{3}{ }^{2-}, \mathrm{NO}_{3}{ }^{-}$etc.) is well studied as one

Electronic supplementary material. The online version of this article (doi: 10.4149/gpb_2016053) contains supplementary material, which is available to authorized users.

Correspondence to: Veronika Hýsková, Department of Biochemistry, Faculty of Science, Charles University, Hlavova 2030, Prague 2, 128 43, Czech Republic

E-mail: veronika.hyskova@natur.cuni.cz of the most common abiotic stress, much less attention is devoted to plant hypoosmotic stress. The high salt concentration results in a decrease of soil water potential and thus a decrease water uptake by roots, a decreased turgor, closed stomata and therefore a decreased availability of $\mathrm{CO}_{2}$ for ribulose-1,5-bisphosphate carboxylase/oxygenase (Rubisco) and reduced photosynthesis (Kosova et al. 2011; Isayenkov 2012; Tang et al. 2014). Salt stress causes substantial transcriptomic and metabolic reprogramming, which may in turn affect growth and development (Pétriacq et al. 2013; Deinlein et al. 2014). High salinity increases respiration and reactive oxygen species (ROS) generation, which cause oxidative stress. Besides antioxidant ascorbate-glutathione cycle, plant phenolic compounds such as flavonoids are 
regarded as crucial compounds that are accumulated under stress and that can eliminate toxic effect of harmful ROS. In addition to oxidative stress, salt ions invoke osmotic stress and an imbalance in intracellular ion and redox homeostasis (Nawaz et al. 2010; Bartwal et al. 2013; Abbasi et al. 2016). Osmotic stress can be alleviated by synthesis of osmotically active compounds (Gzik 1996; Garg et al. 2002; Abebe et al. 2003; Pandolfi et al. 2010) or specific proteins (e.g. heat shock proteins, HSPs) (Wang et al. 2003; Doubnerova and Ryslava 2014). Nevertheless, $\mathrm{Na}^{+}$ions in saline soils are toxic due to their unfavorable effect on $\mathrm{K}^{+}$nutrition and cytosolic enzyme activities (Shi et al. 2000). The enormous negative membrane potential across the plasma membrane of plant cells favors the passive transport of $\mathrm{Na}^{+}$into cells (Zhu 2003). Non-selective cation channels (NSSCs) catalyzing passive fluxes of cations through plasma membranes were proposed to form a major pathway for $\mathrm{Na}^{+}$entry into plants (Demidchik and Maathuis 2007). However avoidance of $\mathrm{Na}^{+}$ toxicity and maintenance of high $\mathrm{K}^{+} / \mathrm{Na}^{+}$ratio in cytoplasm is crucial for the normal function of cellular metabolism (Conde et al. 2011; Pitann et al. 2013). Main mechanisms, which prevents accumulation of $\mathrm{Na}^{+}$ions in cytoplasm, are active $\mathrm{Na}^{+}$efflux, restriction of $\mathrm{Na}^{+}$influx and sequestration of $\mathrm{Na}^{+}$ions in the vacuole (Shi et al. 2000; Abbasi et al. 2016).

On the other hand, hypoosmotic stress in plants causes less severe consequences than hyperionic stress and also than hypoosmotic stress in animal cells due to the presence of the cell walls. The metabolic changes accompanying hypoosmotic stress-induced ROS generation mediated by NADPHoxidases (Kurusu et al. 2012), hypoosmotic stress-induced increase in membrane fluidity, increased tonoplast proton pumps activity and possible inhibition of aerobic metabolism (Ozolina et al. 2011) have not been fully clarified yet.

It was shown that $25-100 \mathrm{mM}$ concentration of $\mathrm{NaCl}$ in the rooting medium of a cucumber resulted in marked depression of the net photosynthesis (Drew et al. 1990; Badawi et al. 2004). Decreased photosynthesis is related to lower photosynthetic yield in the form of NADPH. However, reduction equivalent NADPH is indispensable coenzyme in antioxidant systems, biosynthetic processes and plant defense responses. Therefore, we wanted to find out if NADP-dependent enzymes producing NA$\mathrm{DPH}$ could compensate photosynthetic insufficiency in a salt stress plants. In addition to major NADP-enzymes: glucose-6-phosphate dehydrogenase (G6PDH, EC 1.1.1.49), NADP-isocitrate dehydrogenase (NADP-ICDH, EC 1.1.1.42), NADP-malic enzyme (NADP-ME, EC 1.1.1.40), non-phosphorylating NADP-dependent glyceraldehyde3-phosphate dehydrogenase (NP-GAPDH, EC 1.2.1.9) and NADP-shikimate dehydrogenase (SDH, EC 1.1.1.25), which rather catalyzes reaction in which NADPH is metabolized, also less abundant enzymes were studied: NADP-ribose1-dehydrogenase (ribose-1-DH, EC 1.1.1.115), NADP- glucose-1-dehydrogenase (glucose-1-DH, EC 1.1.1.119), NADP-galactose-1-dehydrogenase (galactose-1-DH, EC 1.1.1.120), NADP-gluconate 2-dehydrogenase (gluconate2-DH, EC 1.1.1.215) and NADP-glycerol-2-dehydrogenase (glycerol-2-DH, EC 1.1.1.156), with substrates in addition to $\mathrm{NADP}^{+}$: D-ribose, D-glucose, D-galactose, D-gluconate and D-glycerol, respectively.

The aim of our study was to show how salt stress $(100 \mathrm{mM}$ $\mathrm{NaCl})$ and hypoosmotic stress in cucumber seedlings $(\mathrm{Cu}$ cumis sativa L.) affect the activity of both the main and the less abundant NADP-dependent enzymes producing NA$\mathrm{DPH}$ and the ratio of NADPH/NADP ${ }^{+}$. Furthermore, other parameters characterizing stress such as relative water content (RWC), the $\mathrm{Na}^{+} / \mathrm{K}^{+}$ratios, the amount of compounds with antioxidative properties, the amount of Rubisco and HSP70 protein were compared. The salt stress was carried out in $\mathrm{NaCl}$ solution, hypoosmotic in distilled water. Both treatments involve also mechanical stress, changed oxygen availability and possible nutrition stress, therefore the comparison enables to study the only effect of $\mathrm{NaCl}$. Plants grown in soil were used to evaluate the differences from real conditions.

\section{Materials and Methods}

\section{Plant material}

Cucumis sativa L. cv. Jogger F1 plants were grown in a greenhouse under 14 -h photoperiod [overall integrated mid-values were ca $500 \mu \mathrm{mol}$ (quantum) $\mathrm{m}^{-2} \cdot \mathrm{s}^{-1}$ ], 22/18 ${ }^{\circ} \mathrm{C}$ day/night temperature and relative humidity ca $80 \%$. Cucumber seeds were allowed germinated and developed onto wet cotton wool for 1 week. Seedlings (21) were transferred into 0.51 pots with soil (commercial horticultural substrate) and were grown in a greenhouse for next 4-5 weeks. One third of plants serves as group of control plants, which persevere in the soil, whereas remaining plants were extracted from the soil, their roots were washed thoroughly and one third was transferred to 1-liter bucket with 100 $\mathrm{mM} \mathrm{NaCl}$ solution (group of $100 \mathrm{mM} \mathrm{NaCl}$ stressed plants) and one third to 1-liter bucket with distilled water (group of hypoosmotically stressed plants). The samples were collected 2 h (day zero), 1, 2 and 3 days after salt application from upper leaves and from roots. Four different biological experiments were done.

\section{Determination of relative water content (RWC)}

Determination of RWC was done according to Sharp et al. (1990) and calculated as (FW - DW $) /($ TFW $-\mathrm{DW}) \times 100$, where FW is fresh weight, DW drought weight and TFW fully turgid fresh weight. 
Determination of $\mathrm{Na}^{+}$and $\mathrm{K}^{+}$ions by AAS

The real concentration of $\mathrm{Na}^{+}$and $\mathrm{K}^{+}$ions in leaves and roots was determined using atomic absorption spectrometry (AAS), spectrometer AAS 3 (Carl Zeiss Jena, Germany) in atomic emission spectrometry (AES) mode at $589.0 \mathrm{~nm}$ and $766.5 \mathrm{~nm}$ with spectral width of $0.3 \mathrm{~nm}$ and $0.1 \mathrm{~nm}$, respectively, after atomization/excitation in flame. Samples for $\mathrm{Na}^{+}$determination were prepared by extraction of $1 \mathrm{~g}$ of plant material in $3 \mathrm{ml}$ of distilled water and by centrifugation of extracts at $16,600 \times g$ and $4^{\circ} \mathrm{C}$ for $15 \mathrm{~min}$. Supernatants were stored at $-25^{\circ} \mathrm{C}$ until measurements.

\section{Determination of total phenolics and flavonoids content}

Cucumber leaves $(2.5 \mathrm{~g})$ were extracted with $50 \mathrm{ml}$ of $80^{\circ} \mathrm{C}$ distilled water for $20 \mathrm{~min}$, extracts were filtrated through 4-layer mull, centrifuged at $9,400 \times g$ and $4^{\circ} \mathrm{C}$ for $15 \mathrm{~min}$ and supernatants filtrated through syringe Schleicher\&Schuell membrane filters with pore diameter of $0.45 \mu \mathrm{m}$. Final sample was used for determination of total phenolics using Folin reagent according to Cai et al. (2004) and of flavonoids according to Liu et al. (2002).

\section{SDS-PAGE and quantification of Rubisco and HSP70}

The soluble proteins in leaves extracts were separated by SDSPAGE (Laemmli 1970). Rubisco (large subunit with relative molecular mass about 55 000) was detected by Coomassie Brilliant Blue staining and quantified. Protein HSP70 was detected immunochemically using specific rabbit polyclonal antibody (Agrisera, Sweeden) on nitrocellulose membrane after transfer of proteins from gel. The visualization was carried out with goat anti-rabbit antibody conjugated with alkaline phosphatase (Sigma, USA) and 5-bromo-4-chloro3-indolyl phosphate/Nitroblue tetrazolium tablet (Sigma, USA) incubation solution. The results were evaluated with program ImageJ.

\section{Determination of soluble proteins}

Soluble proteins were determined by Bradford reagent (Sigma, USA) with bovine serum albumin as the standard (Bradford 1976).

\section{Estimation of $\mathrm{NADP}^{+}$and $\mathrm{NADPH}$ content}

The amount of $1 \mathrm{~g}$ of plant material was inactivated either in $3 \mathrm{ml}$ of $1 \mathrm{M} \mathrm{HClO}_{4}$ at laboratory temperature (for $\mathrm{NADP}^{+}$estimation) or in $3 \mathrm{ml}$ of $0.1 \mathrm{M} \mathrm{NaOH}$ at $100^{\circ} \mathrm{C}$ for 2-5 min (for NADPH estimation). Consequently, $0.02 \mathrm{~g}$ of poly(vinylpolypyrrolidone) (PVP) was added to these mixtures and extracts were centrifuged at $16,600 \times g$ and $4^{\circ} \mathrm{C}$ for $15 \mathrm{~min}$. Then the supernatants were neutralized with $5 \mathrm{M} \mathrm{K}_{2} \mathrm{CO}_{3}$ and $0.1 \mathrm{M} \mathrm{HCl}$, respectively (Mateos et al. 2009).

$\mathrm{NADP}^{+}$was determined enzymatically in $1 \mathrm{ml}$ of reaction mixture containing $100 \mathrm{mM}$ Tris- $\mathrm{HCl}, \mathrm{pH} 7.4 ; 5 \mathrm{mM}$ D-glucose-6-phosphate, $2 \mathrm{mM} \mathrm{MgCl}_{2}, 1 \mathrm{U}$ of G6PDH from Leuconostoc mesenteroides and $100 \mu \mathrm{l}$ of neutralized supernatant. After $30 \mathrm{~min}, 200 \mu \mathrm{l}$ of detection solution $(5 \mathrm{mg} /$ $\mathrm{ml}$ iodonitrotetrazolium violet and $5 \mu \mathrm{g} / \mathrm{ml}$ of phenazine methosulfate) was added and absorbance at $500 \mathrm{~nm}$ was measured in comparison with blank, in which G6PDH was replaced by distilled water.

$\mathrm{NADPH}$ was determined using $1 \mathrm{ml}$ of neutralized supernatant after alkaline inactivation and $200 \mu \mathrm{l}$ of above mentioned detection solution. Absorbance was measured immediately at $500 \mathrm{~nm}$.

\section{Enzyme activity assays}

Approximately $0.5 \mathrm{~g}$ of the plant sample was homogenized with $1.5 \mathrm{ml}$ of extraction buffer containing $100 \mathrm{mM}$ Tris- $\mathrm{HCl}$ $\mathrm{pH} 7.8 ; 5 \mathrm{mM} \mathrm{MgCl}_{2} ; 1 \mathrm{mM}$ EDTA; $1 \mathrm{mM}$ dithiothreitol; $1 \%(\mathrm{v} / \mathrm{v})$ protease inhibitor cocktail for tissue and plant extracts (Sigma, USA). Then $0.02 \mathrm{~g}$ of PVP was added and the homogenate was centrifuged at $16,600 \times g$ and $4^{\circ} \mathrm{C}$ for $15 \mathrm{~min}$. The activities of major NADP-dependent enzymes were determined in supernatant (further assigned as plant extract) by monitoring of increase in absorbance at $340 \mathrm{~nm}$, which corresponds to liberating product NADPH. One unit of enzyme activity is defined as $\mu \mathrm{mol}$ of liberating product per min at $20^{\circ} \mathrm{C}$.

The reaction mixture for determination of G6PDH activity contains: $100 \mathrm{mM}$ Tris- $\mathrm{HCl}, \mathrm{pH}$ 7.6; 5 mM Dglucose-6-phosphate; $2 \mathrm{mM} \mathrm{MgCl}_{2}$ and $0.2 \mathrm{mM} \mathrm{NADP}^{+}$. Determination of NADP-ICDH activity was carried out in $100 \mathrm{mM}$ Tris- $\mathrm{HCl}, \mathrm{pH} 7.4 ; 2 \mathrm{mM}$ isocitrate; $2 \mathrm{mM} \mathrm{MgCl}_{2}$ and $0.2 \mathrm{mM} \mathrm{NADP}^{+}$. NADP-ME activity was determined in $100 \mathrm{mM}$ Tris- $\mathrm{HCl}, \mathrm{pH}$ 7.4; $10 \mathrm{mM}$ L-malate; $2 \mathrm{mM}$ $\mathrm{MgCl}_{2}$ and $0.2 \mathrm{mM} \mathrm{NADP}^{+}$and $\mathrm{SDH}$ in reaction mixture containing $100 \mathrm{mM}$ 2-amino-2-methyl-1-propanol-NaOH, $\mathrm{pH} 9 ; 3 \mathrm{mM}$ shikimate and $0.2 \mathrm{mM} \mathrm{NADP}^{+}$. NP-GAPDH was determined using coupled reaction: firstly $1 \mathrm{U} / \mathrm{ml}$ of aldolase was incubated with $10 \mathrm{mM}$ D-fructose-1,6bisphosphate, $100 \mathrm{mM}$ Tris $\mathrm{HCl}, \mathrm{pH} 7.4 ; 2 \mathrm{mM} \mathrm{MgCl}_{2}$; and $0.2 \mathrm{mM} \mathrm{NADP}^{+}$for $1 \mathrm{~h}$ and after that the plant extract was added. The glucose-1-DH, galactose-1-DH, ribose-1-DH, gluconate-2-DH and glycerol-2-DH were determined in $100 \mathrm{mM}$ Tris- $\mathrm{HCl}, \mathrm{pH} 7.4 ; 0.2 \mathrm{mM} \mathrm{NADP}^{+}$and particular substrate in $10 \mathrm{mM}$ concentration (D-glucose, D-galactose, $\mathrm{D}$-ribose, D-gluconate and D-glycerol, respectively). The volume of all reaction mixtures was $1 \mathrm{ml}$ and reactions were started with 50-100 $\mu$ l of the plant extract. Together with reaction mixtures also blanks without $\mathrm{NADP}^{+}$or substrates were processed. 


\section{Statistical analysis}

The enzyme activity measurements, RWC and $\mathrm{Na}^{+}$and $\mathrm{K}^{+}$ determination were processed in 3 samples in individual experimental day and were presented as mean \pm SD. At least 4 biological experiments were performed. Statistically significant differences in the mean values were tested by Student's $t$-test at $p \leq 0.05$.

\section{Results and Discussion}

The significant effect of salt stress on RWC and ion balance is only mild under hypoosmotic conditions

The consequences of salt or hypoosmotic stress in $\mathrm{cu}$ cumber plants was followed by determination of RWC (Fig. 1) and the $\mathrm{Na}^{+}$and $\mathrm{K}^{+}$ion contents by AES (Fig. 2). After 3 days of salt stress, RWC in leaves decreased up to $60 \%$ compared to $92 \%$ RWC in controls grown in soil with regular watering. Hypoosmotic stress caused by exposure of cucumber plants to distilled water did not affect RWC at the beginning of stress but a slight decrease was found after 3 days of stress (Fig. 1). Hypoosmotic stress could affect the plant metabolism, the plant cells were not able to maintain turgor and water in the cells and thus RWC was decreased (but not as much as in salt stress). In salt-stressed plants the concentration of $\mathrm{Na}^{+}$ significantly increased in both the leaves (up to 8-fold compared to controls grown in soil) and the roots (up to 15-fold compared to controls grown in soil) (Fig. 2A,B). In contrast, the concentration of $\mathrm{K}^{+}$ions kept decreasing in salt-stressed plants. Especially in the roots, the concentration of $\mathrm{K}^{+}$was almost undetectable after 3 days of salt stress (Fig. 2C,D). Hypoosmotic stress mostly did

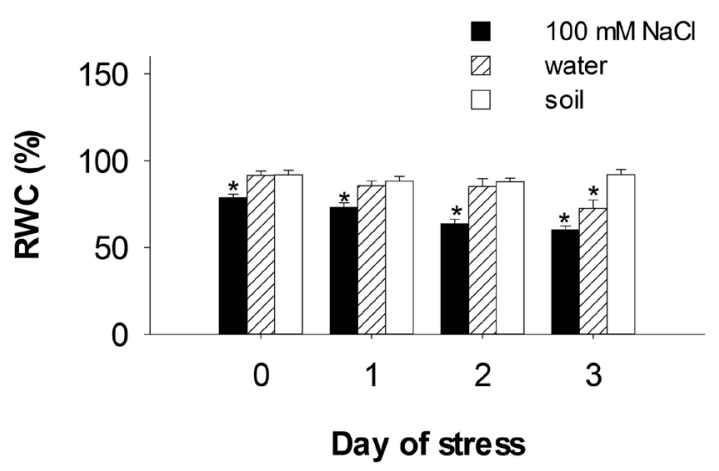

Figure 1. The relative water content (RWC) in leaves of cucumber plants stressed by salt $(100 \mathrm{mM} \mathrm{NaCl})$ and hypoosmotic stress caused by distilled water in comparison with plants grown in soil. * The significant differences from controls grown in soil with $p \leq$ 0.05 calculated by $t$-test. not significantly affect the $\mathrm{Na}^{+}$and $\mathrm{K}^{+}$concentrations in leaves and roots (Fig. 2).

The significant decrease in RWC (Fig. 1), sharply increased content of $\mathrm{Na}^{+}$ions in salt-stressed leaves and roots and decrease in the content of $\mathrm{K}^{+}$ions, especially in the roots (Fig. 2), are consistent with previous studies
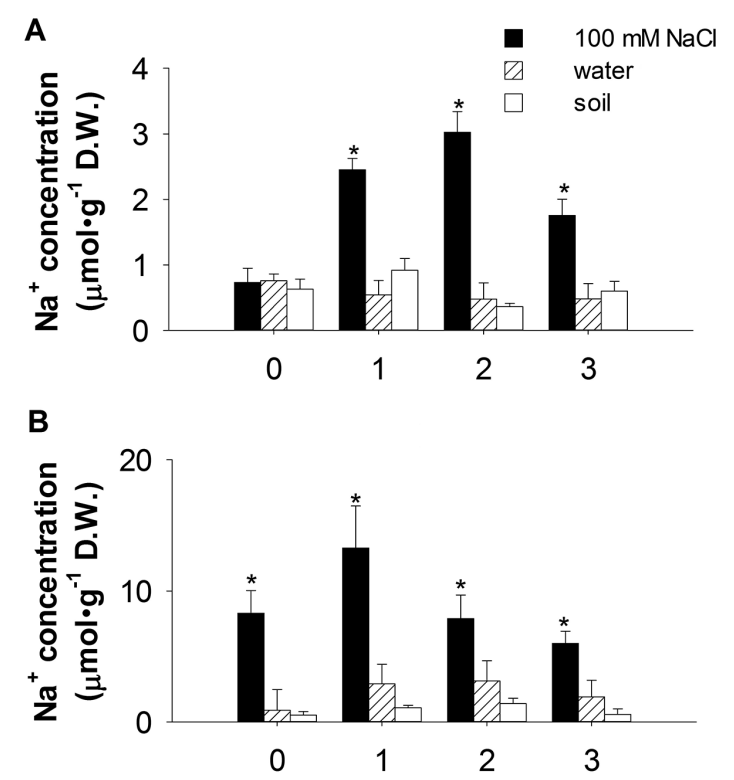

C

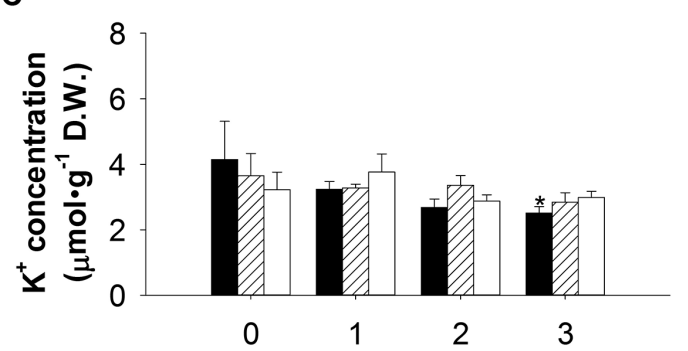

D

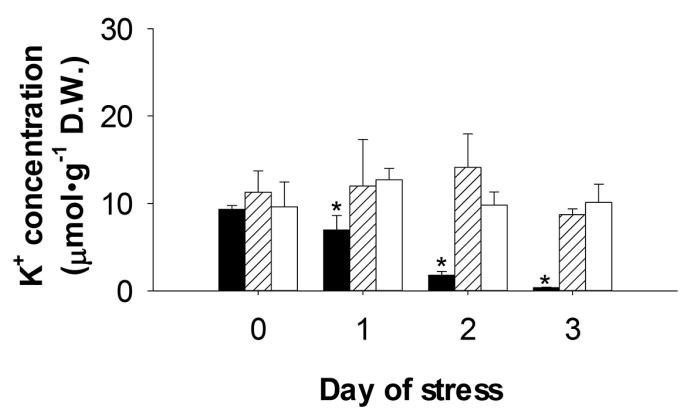

Figure 2. The concentration of $\mathrm{Na}^{+}$and $\mathrm{K}^{+}$ions in leaves $(\mathrm{A}, \mathrm{C})$ and roots $(\mathbf{B}, \mathbf{D})$ of cucumber plants stressed by salt $(100 \mathrm{mM} \mathrm{NaCl})$ and hypoosmotic stress caused by distilled water in comparison with plants grown in soil. ${ }^{\star}$ The significant differences from controls grown in soil with $p \leq 0.05$ calculated by $t$-test. The concentration is related to dry weight (D.W.). 
dealing with other plant species under salt stress (Aleman et al. 2011; Abbasi et al. 2016). These changes in the $\mathrm{K}^{+}$/ $\mathrm{Na}^{+}$ratio under salt stress have already been characterized. This phenomenon, which can be used to ameliorate the toxicity of $\mathrm{Na}^{+}$ions, consists in an increase in the $\mathrm{K}^{+}$content in the extrinsic environment. However, the maintenance of a high $\mathrm{K}^{+} / \mathrm{Na}^{+}$ratio in shoots is correlated with salinity tolerance in glycophytes (such as cucumber) (Hauser and Horie 2010). $\mathrm{Na}^{+}$sequestration in the vacuole in possible combination with $\mathrm{Na}^{+}$exclusion from the roots might be a crucial strategy for the viability of plants under severe salinity stress (Zhu 2003; Hauser and Horie 2010). Moreover, vacuolar sequestration not only lowers the $\mathrm{Na}^{+}$concentration in the cytoplasm but also contributes to osmotic adjustment (Zhu 2003). It was shown in Arabidopsis that two genes encoding plasma membrane NADPH oxidase are involved in ROSdependent modulation of $\mathrm{Na}^{+} / \mathrm{K}^{+}$homeostasis through activation of plasma membrane $\mathrm{Ca}^{2+}$-permeable channels resulting in increases in the cytoplasmic $\mathrm{Ca}^{2+}$ levels $(\mathrm{Ma}$ et al. 2012). It is known that $\mathrm{Ca}^{2+}$ ions activated the saltstress signaling pathway (SOS, salt overly sensitive); the SOS1 gene encodes a $\mathrm{Na}^{+} / \mathrm{H}^{+}$antiporter eliminating toxic ions (Ramezani et al. 2013).

A

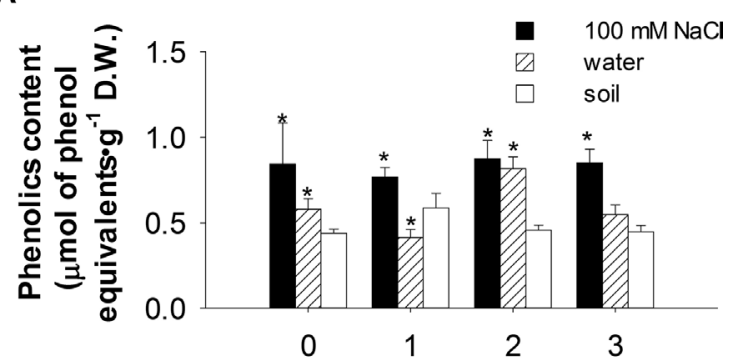

B

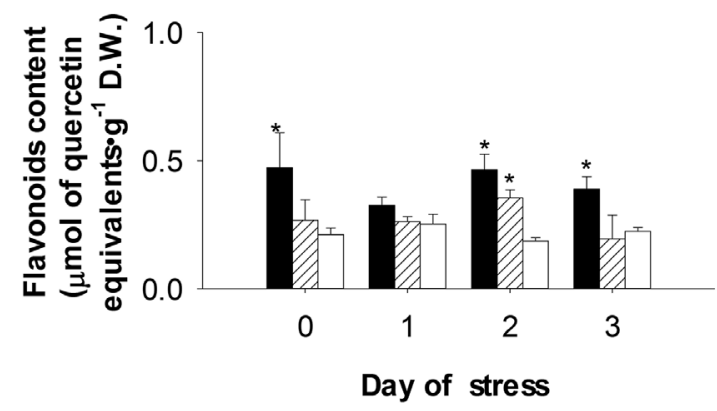

Figure 3. The content of total phenolics (A) and flavonoids (B) in leaves of cucumber plants stressed by salt $(100 \mathrm{mM} \mathrm{NaCl})$ and hypoosmotic stress caused by distilled water in comparison with plants grown in soil. * The significant differences from controls grown in soil with $p \leq 0.05$ calculated by $t$-test. The content of phenolics and flavonoids is related to dry weight (D.W.).
A Day of stress

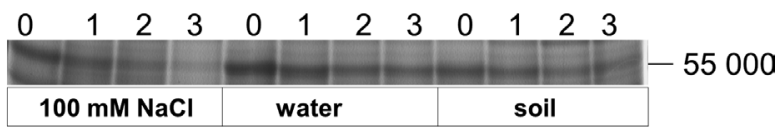

B

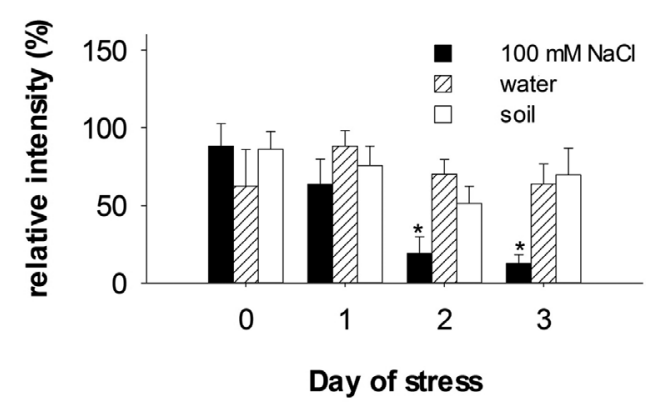

Figure 4. Detection of Rubisco protein in 10\% polyacrylamide gel after SDS-electrophoresis (A) followed by densitometric quantification using ImageJ program (B). The equal amount of soluble proteins $(50 \mu \mathrm{g})$ was applied to each line. ${ }^{*}$ The significant differences from controls grown in soil with $p \leq 0.05$ calculated by $t$-test. $100 \%$ corresponds to the highest value.

Both stresses stimulated increased content of total phenolics and flavonoids

Stress is often followed by the synthesis of compounds with antioxidant properties, such as phenolics including flavonoids. Salt and hypoosmotic stress induced a higher leaf content of total phenolic compounds (Fig. 3A) and content of flavonoids (Fig. 3B). Particularly after 2 days of stress, compared to plants grown in soil, the content of phenolics was increased by salt and hypoosmotic stress 1.9-fold and 1.8 -fold, respectively, and the content of flavonoids was increased 2.5-fold and 1.9-fold, respectively (Fig. 3A,B). In plants, phenolics such as flavonoids and other phenylpropanoids are generally regarded as crucial defense compounds that act as scavengers of harmful ROS. The antioxidant action of phenolic compounds is related to their ability to donate electrons or hydrogen atoms and to the nucleophilic character of the aromatic rings, which increases their chelating ability. In addition, the hydroxyl groups of phenolics are able to bind iron ions and thus suppress the superoxide-driven Fenton reaction (Bartwal et al. 2013).

Salt stress decreased the content of Rubisco but increased the amount of HSP70

The content of total soluble proteins was determined in both groups of stressed plants. As a consequence of the stress, photosynthetic proteins can be degraded, especially the most abundant protein Rubisco (Galmes et al. 2013). SDS electrophoresis followed by densitometric analysis of the 
band corresponding to the large Rubisco subunit revealed a reduced amount of this protein in salt-stressed plants, in contrast to hypoosmotically stressed plants and plants grown in soil (Fig. 4). However, the content of soluble proteins in salt-stressed leaves was slightly enhanced during the first two days (Fig. 5), probably due to increased expression of defense proteins including chaperons HSP70. In the course of salt stress, the amount of protein HSP70 increased in the leaves (Fig. 6). A number of functions in abiotic stress were proposed for plant HSP70, e.g. fine-tuned regulation of the stomatal aperture and modulation of the transcriptional and physiological responses to abscisic acid (Clement et al. 2011), participation in the photosystem II D1 protein repair cycle (Yokthongwattana et al. 2001) and the maturation of chloroplast proteins in higher plants (Mulo et al. 2012), the function in stress signaling, the cooperation with osmolytes and, of course, the function in protein folding and in preventing aggregation and denaturation (Doubnerova and Ryslava 2014).

\section{NADPH cycling in stressed plants}

In general, stresses cause high energy consumption and enhancement of respiration with linked production of ROS

\section{A}

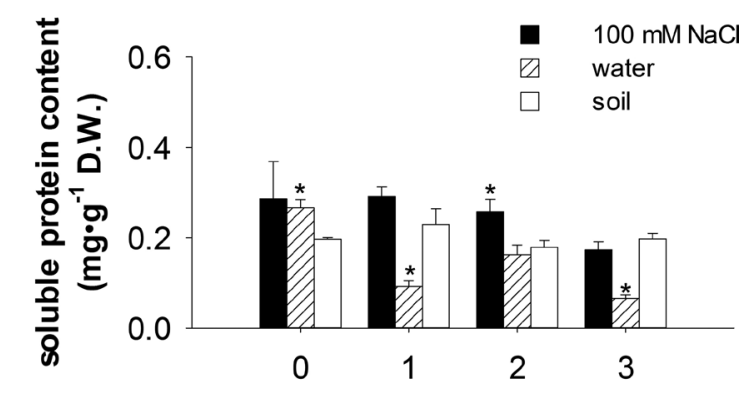

B

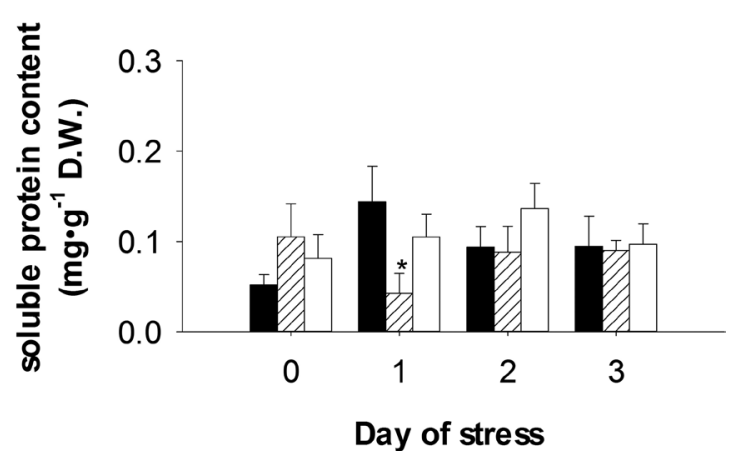

Figure 5. The concentration of soluble proteins in leaves $(\mathbf{A})$ and roots $($ B $)$ of cucumber plants stressed by salt $(100 \mathrm{mM} \mathrm{NaCl})$ and hypoosmotic stress caused by distilled water in comparison with plants grown in soil. ${ }^{*}$ The significant differences from controls grown in soil with $p \leq 0.05$ calculated by $t$-test. The concentration is related to dry weight (D.W.).
A

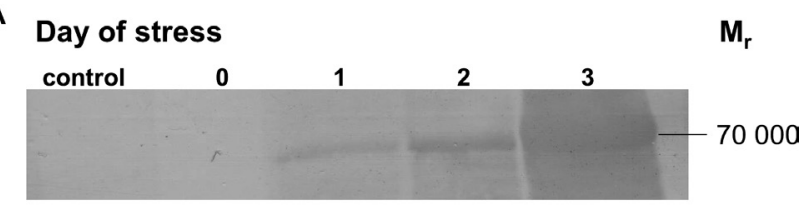

B

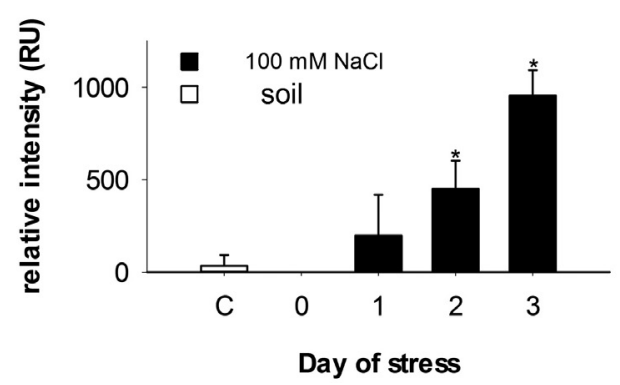

Figure 6. Immunochemical detection (A) of the protein HSP70 in leaves samples of plants exposed to $100 \mathrm{mM}$ salt stress in course of stress compared to control $\mathrm{C}$ grown in soil. The equal amount of the soluble proteins $(50 \mu \mathrm{g})$ was applied to each line. Three representative blots were analyzed using ImageJ program (B). R.U. means relative units corresponding to peak area after conversion of bands into lane profile plots. ${ }^{*}$ The significant differences in relative intensity from controls grown in soil with $p \leq 0.05$ calculated by $t$-test.

(De Block et al. 2005). Plasma membrane NADPH-oxidase is considered to be an important producer of ROS (Ma et al. 2012). The depletion of NADPH pools and decreased supplementation of NADPH to antioxidant systems is related not only to an increase in the ROS content but also to protein and lipid peroxidation and to DNA damage (Pétriacq et al. 2013; Jakubowska et al. 2015).

The main source of NADPH and ATP in plants is lightdriven photosynthetic flow. However, the salt stress leads to insufficient electron flow and reduced activity of photosynthetic enzymes (Bartwal et al. 2013).

Estimation of the $\mathrm{NADP}^{+}$content indicated its increase in salt-stressed leaves, whereas the concentration of $\mathrm{NADP}^{+}$ in roots tended to decrease, although insignificantly (Fig. $7 \mathrm{~A}, \mathrm{C})$. Salt stress did not affect the content of NADPH in either leaves or roots (Fig. 7B,D). The decrease in the NA$\mathrm{DPH} / \mathrm{NADP}^{+}$ratio was also documented for other systems of plant-salt stressor, e. g. for glycophyte plants Brassica juncea, for halophyte plants Sesuvium portulacastrum L. (Srivastava et al. 2015), for olive plants (Valderrama et al. 2006) and rice suspension cells (Zhang et al. 2013). Hypoosmotic stress induced enhancement of the NADPH content in the roots (Fig. 7D) and, on the other hand, a decrease in $\mathrm{NADP}^{+}$in the leaves (Fig. 7A).

Since salt stress and hypoosmotic stress affected the $\mathrm{NADP}^{+} / \mathrm{NADPH}$ ratio, the activity of NADPH-providing enzymes was studied. 
Hypoosmotic stress enhanced the activities of major NADPdependent enzymes more than salt stress

Immediately following application of hypoosmotic stress, the activity of NADP-dependent enzymes in leaves decreased compared to plants grown in soil. However, after 3 days, a defense response appeared in the form of substantially increased specific activities in hypoosmotically stressed leaves:
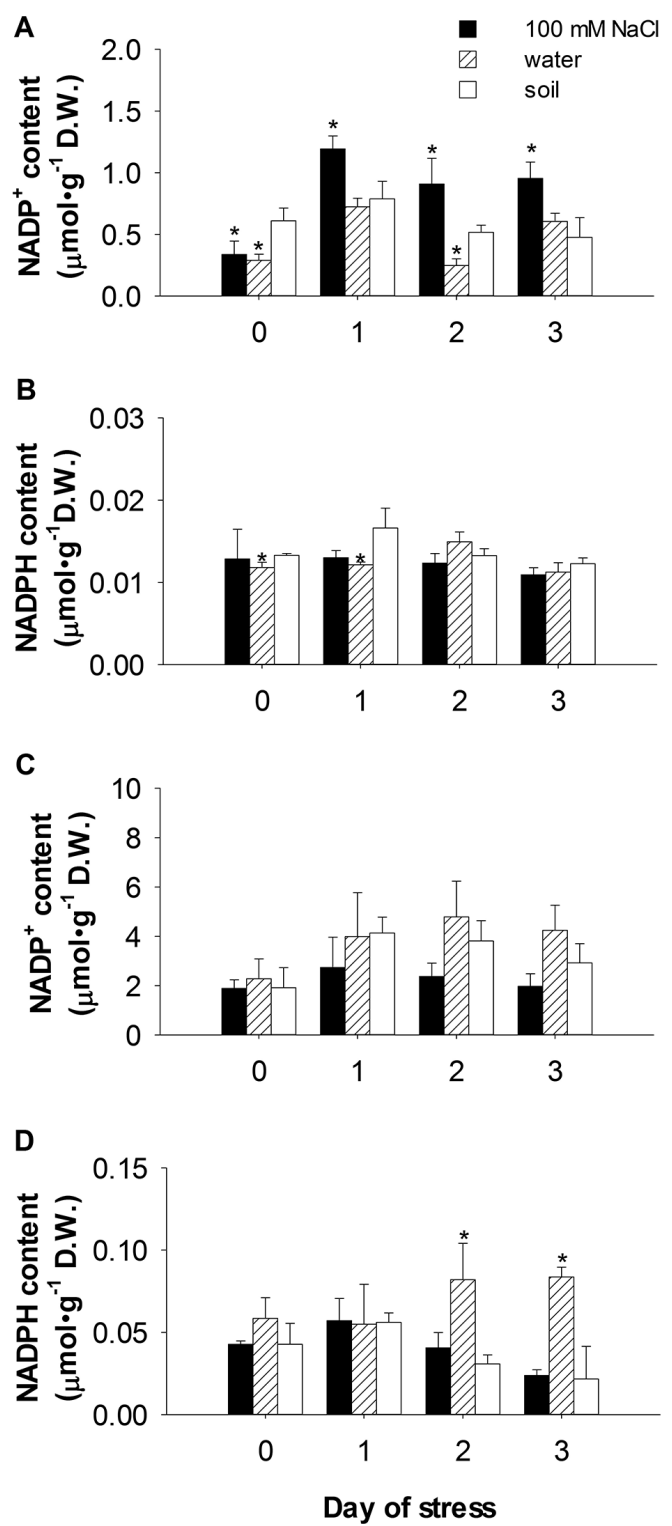

Figure 7. The estimation of $\mathrm{NADP}^{+}$and NADPH concentration in leaves $(\mathbf{A}, \mathbf{B})$ and roots $(\mathbf{C}, \mathbf{D})$ of cucumber plants stressed by salt $(100 \mathrm{mM} \mathrm{NaCl})$ and hypoosmotic stress caused by distilled water in comparison with plants grown in soil. ${ }^{*}$ The significant differences from controls grown in soil with $p \leq 0.05$ calculated by $t$-test. The concentration is related to dry weight (D.W.).
A

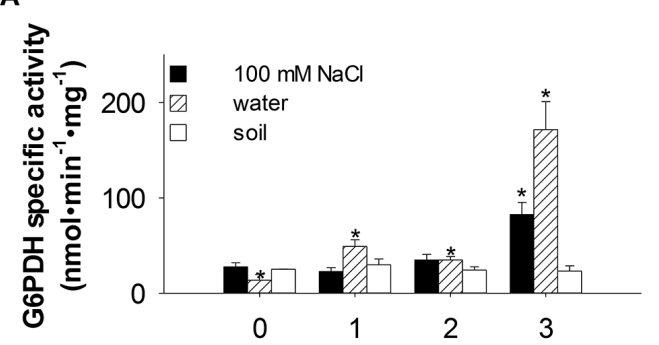

B

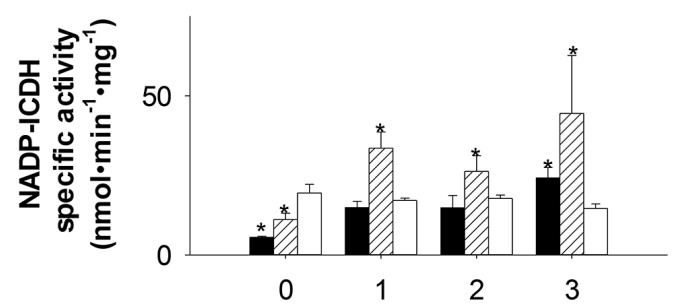

$\mathrm{C}$

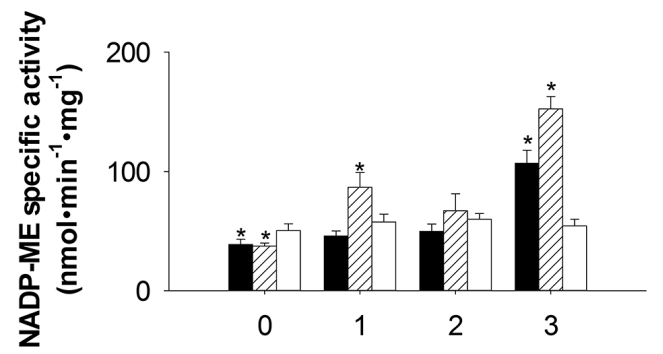

D

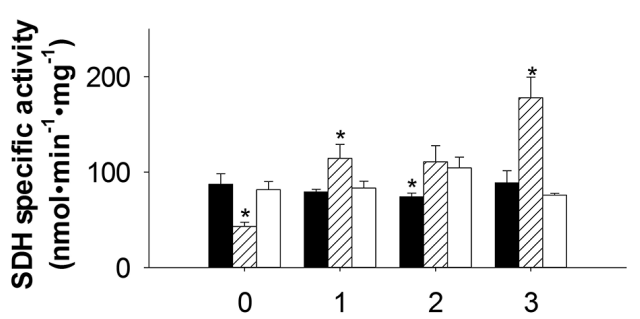

E

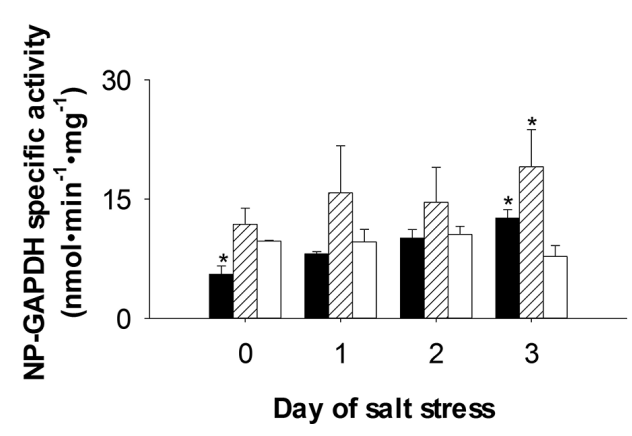

Figure 8. Specific activity of major NADP-dependent enzymes: G6PDH (A), NADP-ICDH (B), NADP-ME (C), SDH (D) and NP-GAPDH (E) in leaves of cucumber plants stressed by salt (100 $\mathrm{mM} \mathrm{NaCl}$ ) and hypoosmotic stress caused by distilled water in comparison with plants grown in soil. ${ }^{\star}$ The significant differences from controls grown in soil with $p \leq 0.05$ calculated by $t$-test. 
increases in the activities of G6PDH (7.4-fold), NADP-ME (2.8-fold), NADP-ICDH (3.1-fold), NP-GAPDH (2.5-fold) and SDH (2.3-fold) were observed (Fig. 8). Plants exposed to salt stress for three days exhibited significantly increased specific activities of major NADPH-providing enzymes in leaves compared to non-stressed controls grown in soil, specifically G6PDH (3.5-fold), NADP-ME (2-fold), NADPICDH (1.7-fold) and NP-GAPDH (1.6-fold) (Fig. 8). Thus, compared to plants treated with distilled water, $100 \mathrm{mM}$
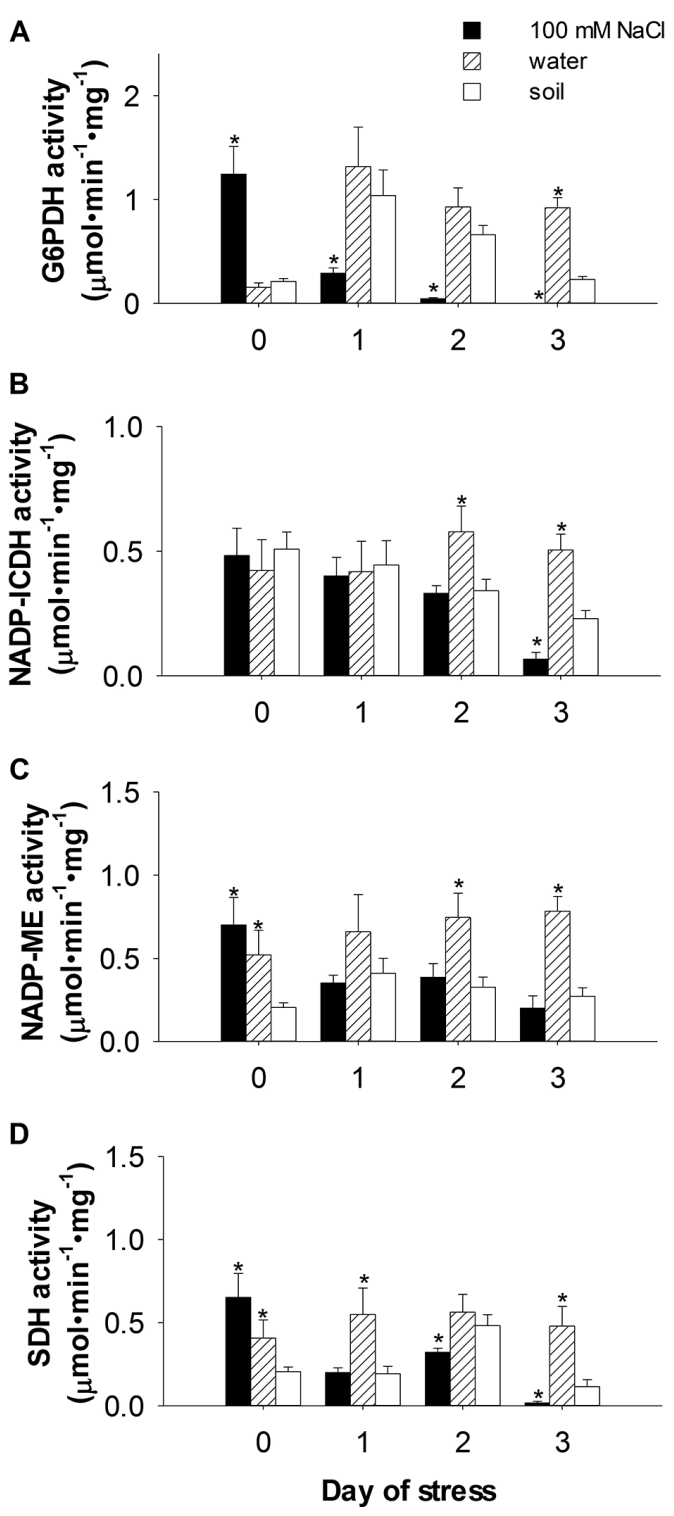

Figure 9. Specific activity of major NADP-dependent enzymes: G6PDH (A), NADP-ICDH (B), NADP-ME (C) and SDH (D) in roots of cucumber plants stressed by salt $(100 \mathrm{mM} \mathrm{NaCl})$ and hypoosmotic stress caused by distilled water in comparison with plants grown in soil. ${ }^{*}$ The significant differences from controls grown in soil with $p \leq 0.05$ calculated by $t$-test.
$\mathrm{NaCl}$ caused significantly reduced activities of the abovementioned NADP enzymes, especially after 3 days of stress (Fig. 8, Table S1 in Supplementary material). The reduced activities of the main NADP-enzymes in the leaves due to salt stress are consistent with increased unutilized $\mathrm{NADP}^{+}$ content (Fig. 7A). Nevertheless, higher level of $\mathrm{NADP}^{+}$can act as an activator of NADP-enzymes such as G6PDH. The specific activity of SDH (enzyme which prefers NADPH to NADP) was mainly unchanged in salt-stressed plants (Fig. 8). However, SDH activities calculated per fresh weight increased at the beginning of stress (data not shown). SDH forms shikimate in the shikimate pathway preceding the phenylpropanoid pathway leading to biosynthesis of a wide range of phenylpropanoid compounds with protective and antioxidative properties (Tzin and Galili 2010). It probably participates in the increased content of total phenolics and flavonoids in the course of salt stress (Fig. 3). On the other hand, the pathway from shikimate to phenolic compounds through aromatic amino acids is very complex with different regulation points and thus directing the metabolic flow can cause the accumulation of phenolics.

It could be concluded from previous studies mostly concerning only one enzyme that particular NADP-dependent enzymes such as G6PDH, NADP-ICDH or NADP-ME are related to plant defense responses against abiotic stress (Sun et al. 2003; Chi et al. 2004; Valderrama et al. 2006; Leterrier et al. 2007; Liu et al. 2007a, 2007b; Li et al. 2011; Molina et al. 2011; Cardi et al. 2014; Hyskova Doubnerova et al. 2014; Bouthour et al. 2015). However, a comprehensive study concerning a broader spectrum of NADP-dependent enzymes is still lacking. Various functions of NADP-dependent enzymes during abiotic stress have been suggested (Doubnerova and Ryslava 2012): e.g. the involvement of G6PDH in the regulation of $\mathrm{Na}^{+} / \mathrm{H}^{+}$antiporter through providing NADPH for plasma membrane NADPH-oxidase as an adaptation to salt stress (Li et al. 2011), the participation of NADP-ICDH in supplying carbon skeletons for nitrogen assimilation in rice exposed to cold ( $\mathrm{Lu}$ et al. 2005) or the involvement of NP-GAPDH in anaerobic tolerance under conditions of submergence or in phosphorus deficiency stress (Pillai et al. 2002; Shenoy and Kalagudi 2005). The activity of some of these enzymes could be stabilized by chaperons, such as HSP70, which was demonstrated for NADP-ME (Lara et al. 2005). The significantly higher content of HSP70 in saltstressed cucumber leaves documented the enhanced demand of this chaperon (Fig. 6).

The increased activities of G6PDH, NADP-ICDH, NADP-ME and SDH were also evident in hypoosmotically stressed roots (Fig. 9). The NADPH content in these roots was pronouncedly increased after 2 and 3 days (Fig. 7D). Compared to both groups of plants grown in soil and in distilled water, the specific activity of major NADP-dependent enzymes in roots is progressively decreased by salt stress 
A

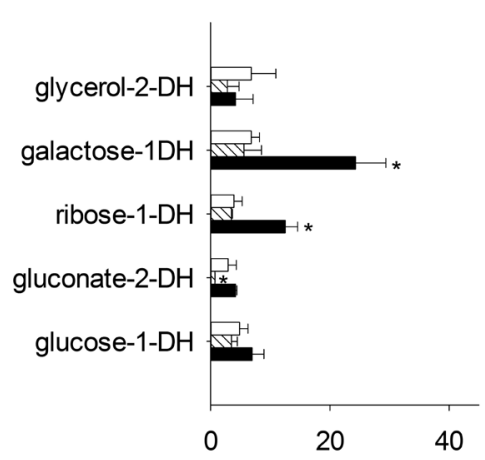

C

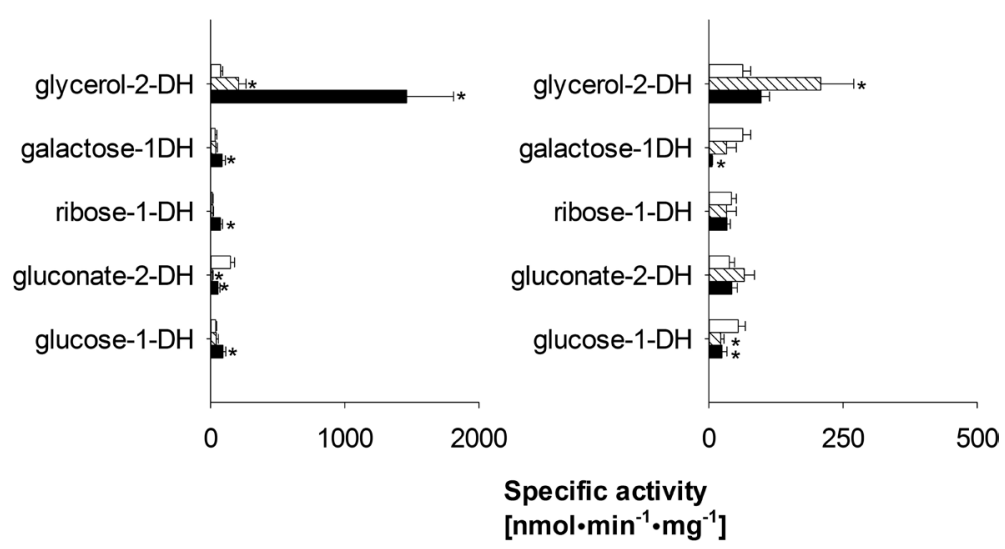

D

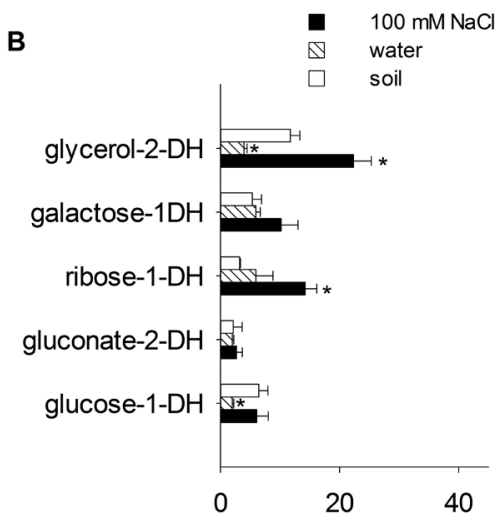

Figure 10. Specific activity of minor NADPdependent enzymes in leaves $(\mathbf{A}, \mathbf{B})$ and roots $(C, D)$ of cucumber plants stressed by salt $(100 \mathrm{mM} \mathrm{NaCl})$ and hypoosmotic stress caused by distilled water in comparison with plants grown in soil at the beginning of experiment $(\mathrm{A}, \mathrm{C})$ and after 1 day $(\mathrm{B}, \mathrm{D}) .{ }^{*}$ The significant differences from controls grown in soil with $p \leq 0.05$ calculated by $t$-test.
(Fig. 9, Table S1). It seems that the ratio of $\mathrm{Na}^{+} / \mathrm{K}^{+}$could be readjusted in leaves in which the metabolic response in the form of increased activity of NADP-dependent enzymes was induced (Figs. 2, 8). The ratios correlate with a study concerned with 17 diverse genotypes of cucumbers under salt stress (Tiwari et al. 2010). On the other hand, strong salt stress exhibits a constantly increasing $\mathrm{Na}^{+} / \mathrm{K}^{+}$ratio and a decrease of the activity of NADP-enzymes in roots (Figs. 2, 9). Furthermore, for example, G6PDH and maybe also some other enzymes are differently regulated by thioredoxin in roots and in leaves.

Involvement of less abundant NADP-enzymes in salt and hypoosmotic stress

In addition to major NADP-enzymes, the activity of glucose1-DH, gluconate-2-DH, ribose-1-DH, galactose-1-DH and glycerol-2-DH was also detectable in cucumber leaves and roots (Fig. 10). Hence the effect of salt and hypoosmotic stress on these enzymes further called minor NADP-dependent enzymes could also be monitored. Whereas the activity of major NADP-dependent enzymes in leaves was increased in a later phase of salt stress, the activity of some minor NADP-dependent enzymes increased at the beginning of stress, namely ribose-1-DH (3.2- and 4.4-fold higher specific activity than controls grown in soil at the beginning of stress and after 1 day, respectively), galactose-1-DH (up to 3.6-fold increase) and glycerol-2-DH (1.9-fold increase) (Fig. 10A,B). The product of galactose-1-DH, galactonolactone, could be a precursor for the glycolysis intermediate - glyceraldehyde-3-phoshate.

Hypoosmotic stress did not induce the activity of minor NADP-dependent enzymes in leaves (Fig. 10A,B) and roots (Fig. 10C,D) except for glycerol-2-DH. The activities of other minor NADP-enzymes were comparable to plants grown in soil. In cucumber roots, the specific activity of glycerol-2-DH increased in both stressed groups (Fig. 10C,D). This enzyme has been studied in yeasts and filamentous fungi, where it fulfills an important function especially during osmotic stress (Morales et al. 2010). Glycerol-2-DH could be part of a "glycerol cycle", which is able to regulate the intracellular concentration of glycerol and generate NADPH at the expense of NADH and ATP (Belmans and Vanlaere 1987; Morales et al. 2010).

NADP-dependent enzymes can be an alternative source of NADPH in case of insufficient electron photosynthetic 
flow (Corpas and Barroso 2014). With regard to implication of NADP-enzymes, it seems that production of NADPH is part of the defense strategy against hypoosmotic stress in cucumber leaves. In addition to the fact that reducing equivalent NADPH serves as a substrate for NADPHoxidase and antioxidant systems, it is also an indispensable coenzyme in biosynthetic processes, including biosynthesis of osmotically active compounds, important amino acids, isoprenoids, flavonoids, lignins and fatty acids (Doubnerova and Ryslava 2012). Simultaneously, NADPH is required for NADPH-thioredoxin reductase, the regulatory enzyme that affects numerous cell processes and oxidative stress-response (Marty et al. 2009).

It can be concluded from this study that hypoosmotic stress is milder than salt stress according to the contents of RWC, $\mathrm{Na}^{+}, \mathrm{K}^{+}$, phenolics and Rubisco. On the other hand, hypoosmotic stress caused more enhanced activities of most NADP-dependent enzymes in leaves and roots than salt stress. However, some minor NADP-enzymes such as galactose-1-DH and ribose-1-DH were involved in defense at the beginning of salt stress. NADP-enzymes could participate in NADPH recycling, but these enzyme activities depend on the experimental design, type of stress and plant tissue.

Acknowledgements. This work was supported by grants from Charles University in Prague (project UNCE 204025/2012). The authors also would like to thank to Prof. Marie Ticha for critical reading of the manuscript.

\section{References}

Abbasi H., Jamil M., Haq A., Ali S., Ahmad R., Malik Z., Parveen (2016): Salt stress manifestation on plants, review. ZemdirbysteAgriculture 103, 229-238

https://doi.org/10.13080/z-a.2016.103.030

Abebe T., Guenzi A. C., Martin B., Cushman J. C. (2003): Tolerance of mannitol-accumulating transgenic wheat to water stress and salinity. Plant Physiol. 131, 1748-1755 https://doi.org/10.1104/pp.102.003616

Aleman F., Nieves-Cordones M., Martinez V., Rubio F. (2011): Root $\mathrm{K}+$ acquisition in plants: The Arabidopsis thaliana model. Plant Cell Physiol. 52, 1603-1612 https://doi.org/10.1093/pcp/pcr096

Badawi G. H., Yamauchi Y., Shimada E., Sasaki R., Kawano N., Tanaka K., Tanaka K. (2004): Enhanced tolerance to salt stress and water deficit by overexpressing superoxide dismutase in tobacco (Nicotiana tabacum) chloroplasts. Plant Sci. 166, 919-928 https://doi.org/10.1016/j.plantsci.2003.12.007

Bartwal A., Mall R., Lohani P., Guru S. K., Arora S. (2013): Role of secondary metabolites and brassinosteroids in plant defense against environmental stresses. J. Plant Growth Regul. 32, 216-232 https://doi.org/10.1007/s00344-012-9272-x
Belmans D., Vanlaere A. (1987): Glycerol cycle enzymes and intermediates during adaption of Dunaliella teriolecta cells to hyperosmotic stress. Plant Cell Environ. 10, 185-190

Bouthour D., Kalai T., Chaffei H. C., Gouia H., Corpas F. J. (2015): Differential response of NADP-dehydrogenases and carbon metabolism in leaves and roots of two durum wheat (Triticum durum Desf.) cultivars (Karim and Azizi) with different sensitivities to salt stress. J. Plant Physiol. 179, 56-63 https://doi.org/10.1016/j.jplph.2015.02.009

Bradford M. M. (1976): A rapid and sensitive method for the quantitation of microgram quantities of protein utilizing the principle of protein-dye binding. Anal. Biochem. 72, 248-254 https://doi.org/10.1016/0003-2697(76)90527-3

Cai Y. Z., Luo Q., Sun M., Corke H. (2004): Antioxidant activity and phenolic compounds of 112 traditional Chinese medicinal plants associated with anticancer. Life Sci. 74, 2157-2184 https://doi.org/10.1016/j.lfs.2003.09.047

Cardi M., Castiglia D., Ferrara M., Guerriero G., Chiurazzi M., Esposito S. (2014): The effects of salt stress cause a diversion of basal metabolism in barley roots: possible different roles for glucose-6-phosphate dehydrogenase isoforms. Plant Physiol. Biochem. 86, 44-54 https://doi.org/10.1016/j.plaphy.2014.11.001

Chi W., Yang J., Wu N., Zhang F. (2004): Four rice genes encoding NADP malic enzyme exhibit distinct expression profiles. Biosci. Biotechnol. Biochem. 68, 1865-1874 https://doi.org/10.1271/bbb.68.1865

Clement M., Leonhardt N., Droillard M. J., Reiter I., Montillet J. L., Genty B., Lauriere C., Nussaume L., Noel L.D. (2011): The cytosolic/nuclear HSC70 and HSP90 molecular chaperones are important for stomatal closure and modulate abscisic acid-dependent physiological responses in Arabidopsis. Plant Physiol. 156, 1481-1492 https://doi.org/10.1104/pp.111.174425

Conde A., Chaves M. M., Geros H. (2011): Membrane transport, sensing and signaling in plant adaptation to environmental stress. Plant Cell Physiol. 52, 1583-1602 https://doi.org/10.1093/pcp/pcr107

Corpas F. J., Barroso J. B. (2014): NADPH-generating dehydrogenases: their role in the mechanism of protection against nitrooxidative stress induced by adverse environmental conditions. Front. Environ. Sci. 2,

De Block M., Verduyn C., De Brouwer D., Cornelissen M. (2005): Poly(ADP-ribose) polymerase in plants affects energy homeostasis, cell death and stress tolerance. Plant J. 41, 95-106 https://doi.org/10.1111/j.1365-313X.2004.02277.x

Deinlein U., Stephan A. B., Horie T., Luo W., Xu G., Schroeder J. I. (2014): Plant salt-tolerance mechanisms. Trends Plant Sci. 19, 371-379 https://doi.org/10.1016/j.tplants.2014.02.001

Demidchik V., Maathuis F. J. (2007): Physiological roles of nonselective cation channels in plants: from salt stress to signalling and development. New Phytol. 175, 387-404 https://doi.org/10.1111/j.1469-8137.2007.02128.x

Doubnerova V., Ryslava H. (2014): Roles of Hsp70 in plant abiotic stress. In: Molecular Approaches in Plant Abiotic Stress. (Eds. R. K. Gaur, P. Sharma), CRC Press, pp. 44-66 
Drew M. C., Hole P. S., Picchioni G. A. (1990): Inhibition by $\mathrm{NaCl}$ of net $\mathrm{CO} 2$ fixation and yield of cucumber. J. Am. Society Horticul. Sci. 115, 472-477

Galmes J., Aranjuelo I., Medrano H., Flexas J. (2013): Variation in Rubisco content and activity under variable climatic factors. Photosynth. Res. 117, 73-90 https://doi.org/10.1007/s11120-013-9861-y

Garg A. K., Kim J. K., Owens T. G., Ranwala A. P., Do Choi Y., Kochian L. V., Wu R. J. (2002): Trehalose accumulation in rice plants confers high tolerance levels to different abiotic stresses. P. Natl. Acad. Sci. U.S.A. 99, 15898-15903 https://doi.org/10.1073/pnas.252637799

Gzik A. (1996): Accumulation of proline and pattern of alphaamino acids in sugar beet plants in response to osmotic, water and salt stress. Environ. Exp. Bot. 36, 29-38 https://doi.org/10.1016/0098-8472(95)00046-1

Hauser F., Horie T. (2010): A conserved primary salt tolerance mechanism mediated by HKT transporters: a mechanism for sodium exclusion and maintenance of high $\mathrm{K}+\mathrm{Na}+$ ratio in leaves during salinity stress. Plant Cell Environ. 33, 552-565 https://doi.org/10.1111/j.1365-3040.2009.02056.x

Hyskova Doubnerova V., Miedzinska L., Dobra J., Vankova R., Ryslava H. (2014): Phosphoenolpyruvate carboxylase, NADPmalic enzyme, and pyruvate, phosphate dikinase are involved in the acclimation of Nicotiana tabacum L. to drought stress. J. Plant Physiol. 171, 19-25 https://doi.org/10.1016/j.jplph.2013.10.017

Isayenkov S. V. (2012): Physiological and molecular aspects of salt stress in plants. Cytol. Genet. 46, 302-318 https://doi.org/10.3103/S0095452712050040

Jakubowska D., Janicka-Russak M., Kabala K., Migocka M., Reda M. (2015): Modification of plasma membrane NADPH oxidase activity in cucumber seedling roots in response to cadmium stress. Plant Sci. 234, 50-59 https://doi.org/10.1016/j.plantsci.2015.02.005

Kosova K., Vitamvas P., Prasil I. T., Renaut J. (2011): Plant proteome changes under abiotic stress-contribution of proteomics studies to understanding plant stress response. J. Proteomics 74, $1301-1322$ https://doi.org/10.1016/j.jprot.2011.02.006

Kurusu T., Nishikawa D., Yamazaki Y., Gotoh M., Nakano M., Hamada H., Yamanaka T., Iida K., Nakagawa Y., Saji H., et al. (2012): Plasma membrane protein OsMCA1 is involved in regulation of hypo-osmotic shock-induced $\mathrm{Ca} 2+$ influx and modulates generation of reactive oxygen species in cultured rice cells. BMC Plant Biology 12, 1-15

https://doi.org/10.1186/1471-2229-12-11

Laemmli U.K. (1970): Cleavage of structural proteins during assembly of head of bacteriophage-T4. Nature 227, 680-685 https://doi.org/10.1038/227680a0

Lara M. V., Drincovich M. F., Muller G. L., Maurino V. G., Andreo C. S. (2005): NADP-malic enzyme and Hsp70: co-purification of both proteins and modification of NADP-malic enzyme properties by association with Hsp70. Plant Cell Physiol. 46, 997-1006

https://doi.org/10.1093/pcp/pci108

Leterrier M., Del Rio L. A., Corpas F. J. (2007): Cytosolic NADPisocitrate dehydrogenase of pea plants: genomic clone charac- terization and functional analysis under abiotic stress conditions. Free Rad. Res. 41, 191-199

https://doi.org/10.1080/10715760601034055

Li J., Chen G., Wang X., Zhang Y., Jia H., Bi Y. (2011): Glucose6-phosphate dehydrogenase-dependent hydrogen peroxide production is involved in the regulation of plasma membrane $\mathrm{H}+$-ATPase and $\mathrm{Na}+\mathrm{H}+$ antiporter protein in salt-stressed callus from Carex moorcroftii. Physiol. Plant. 141, 239-250 https://doi.org/10.1111/j.1399-3054.2010.01429.x

Liu M., Li X. Q., Weber C., Lee C. Y., Brown J., Liu R. H. (2002): Antioxidant and antiproliferative activities of raspberries. J. Agric. Food Chem. 50, 2926-2930 https://doi.org/10.1021/jf0111209

Liu S., Cheng Y., Zhang X., Guan Q., Nishiuchi S., Hase K., Takano T. (2007a): Expression of an NADP-malic enzyme gene in rice (Oryza sativa L.) is induced by environmental stresses; overexpression of the gene in Arabidopsis confers salt and osmotic stress tolerance. Plant Mol. Biol. 64, 49-58 https://doi.org/10.1007/s11103-007-9133-3

Liu Y., Wu R., Wan Q., Xie G., Bi Y. (2007b): Glucose-6-phosphate dehydrogenase plays a pivotal role in nitric oxide-involved defense against oxidative stress under salt stress in red kidney bean roots. Plant Cell Physiol. 48, 511-522 https://doi.org/10.1093/pcp/pcm020

Lu B. B., Yuan Y. Z., Zhang C. F., Ou J. Q., Zhou W., Lin Q. H. (2005): Modulation of key enzymes involved in ammonium assimilation and carbon metabolism by low temperature in rice (Oryza sativa L.) roots. Plant Sci. 169, 295-302

https://doi.org/10.1016/j.plantsci.2004.09.031

Ma L. Y., Zhang H., Sun L. R., Jiao Y. H., Zhang G. Z., Miao C., Hao F. S. (2012): NADPH oxidase AtrbohD and AtrbohF function in ROS-dependent regulation of $\mathrm{Na}+/ \mathrm{K}+$ homeostasis in Arabidopsis under salt stress. J. Exp. Bot. 63, 305-317 https://doi.org/10.1093/jxb/err280

Marty L., Siala W., Schwarzlander M., Fricker M. D., Wirtz M., Sweetlove L. J., Meyer Y., Meyer A. J., Reichheld J. P., Hell R. (2009): The NADPH-dependent thioredoxin system constitutes a functional backup for cytosolic glutathione reductase in Arabidopsis. Proc. Natl. Acad. Sci. U.S.A. 106, 9109-9114 https://doi.org/10.1073/pnas.0900206106

Mateos R. M., Bonilla-Valverde D., del Rio L. A., Palma J. M., Corpas F. J. (2009): NADP-dehydrogenases from pepper fruits: effect of maturation. Physiol. Plant. 135, 130-139 https://doi.org/10.1111/j.1399-3054.2008.01179.x

Molina C., Zaman-Allah M., Khan F., Fatnassi N., Horres R., Rotter B., Steinhauer D., Amenc L., Drevon J. J., Winter P., Kahl G. (2011): The salt-responsive transcriptome of chickpea roots and nodules via deepSuperSAGE. BMC Plant Biol. 11, 1-26 https://doi.org/10.1186/1471-2229-11-31

Morales R. L. C., Castellanos A. D., Zazueta-Sandoval R. (2010): Analysis of glycerol dehydrogenase activities present in Mucor circinelloides YR-1. Anton Leeuw Int. J. G 98, 437-445 https://doi.org/10.1007/s10482-010-9457-x

Mulo P., Sakurai I., Aro E. M. (2012): Strategies for psbA gene expression in cyanobacteria, green algae and higher plants: From transcription to PSII repair. Biochim. Biophys. Acta 1817, 247-257 https://doi.org/10.1016/j.bbabio.2011.04.011 
Nawaz K., Hussain K., Majeed A., Khan F., Afghan S., Ali K. (2010): Fatality of salt stress to plants: Morphological, physiological and biochemical aspects. Afr. J. Biotechnol. 9, 5475-5480

Ozolina N. V., Kolesnikova E. V., Nurminsky V. N., Nesterkina I. S., Dudareva L. V., Tretyakova A. V., Salyaev R. K. (2011): Redoxdependence of transport activity of tonoplast proton pumps: Effects of nitrogen oxide exposure in the course of ontogenesis and of hypo- and hyper-osmotic stress. Biologicheskie Membrany 28, 284-289

Pandolfi C., Pottosin I., Cuin T., Mancuso S., Shabala S. (2010): Specificity of polyamine effects on $\mathrm{NaCl}$-induced ion flux kinetics and salt stress amelioration in plants. Plant Cell Physiol. 51, 422-434 https://doi.org/10.1093/pcp/pcq007

Pétriacq P., de Bont L., Tcherkez G., Gakière B. (2013): NAD: Not just a pawn on the board of plant-pathogen interactions. Plant Signal. Behav. 8, 7-17 https://doi.org/10.4161/psb.22477

Pillai M. A., Lihuang Z., Akiyama T. (2002): Molecular cloning, characterization, expression and chromosomal location of OsGAPDH, a submergence responsive gene in rice (Oryza sativa L.). Theor. Appl. Genet. 105, 34-42 https://doi.org/10.1007/s00122-001-0833-9

Pitann B., Mohamed A. K., Neubert A. B., Schubert S. (2013): Tonoplast $\mathrm{Na}+\mathrm{H}+$ antiporters of newly developed maize (Zea mays) hybrids contribute to salt resistance during the second phase of salt stress. J. Plant Nutr. Soil. Sc. 176, 148-156 https://doi.org/10.1002/jpln.201200597

Ramezani A., Niazi A., Abolimoghadam A. A., Babgohari M. Z., Deihimi T., Ebrahimi M., Akhtardanesh H., Ebrahimie E. (2013): Quantitative expression analysis of TaSOS1 and TaSOS4 genes in cultivated and wild wheat plants under salt stress. Mol. Biotechnol. 53, 189-197 https://doi.org/10.1007/s12033-012-9513-Z

Sharp R. E., Hsiao T. C., Silk W. K. (1990): Growth of the maize primary root at low water potentials: II. Role of growth and deposition of hexose and potassium in osmotic adjustment. Plant Physiol. 9, 1337-1346 https://doi.org/10.1104/pp.93.4.1337

Shenoy V. V., Kalagudi G. M. (2005): Enhancing plant phosphorus use efficiency for sustainable cropping. Biotechnol. Adv. 23, 501-513 https://doi.org/10.1016/j.biotechadv.2005.01.004

Shi H., Ishitani M., Kim C., Zhu J. K. (2000): The Arabidopsis thaliana salt tolerance gene SOS1 encodes a putative $\mathrm{Na}+\mathrm{H}+$ antiporter. Proc. Natl. Acad. Sci. U.S.A. 97, 6896-6901 https://doi.org/10.1073/pnas.120170197

Srivastava A. K., Srivastava S., Lokhande V. H., D‘Souza S. F., Suprasanna P. (2015): Salt stress reveals differential antioxidant and energetics responses in glycophyte (Brassica juncea L.) and halophyte (Sesuvium portulacastrum L.). Frontiers Environ. Sci. 3, 1-9

https://doi.org/10.3389/fenvs.2015.00019

Sun S. B., Shen Q. R., Wan J. M., Liu Z. P. (2003): Induced expression of the gene for NADP-malic enzyme in leaves of Aloe vera L. under salt stress. Acta Biochim. Biophys. Sin. 35, 423-429

Tang X., Mu X., Shao H., Wang H., Brestic M. (2014): Global plant-responding mechanisms to salt stress: physiological and molecular levels and implications in biotechnology. Crit. Rev. Biotechnol. 35, 425-437 https://doi.org/10.3109/07388551.2014.889080

Tiwari J. K., Munshi A. D., Kumar R., Pandey R. N., Arora A., Bhat J. S., Sureja A. K. (2010): Effect of salt stress on cucumber: $\mathrm{Na}+\mathrm{K}+$ ratio, osmolyte concentration, phenols and chlorophyll content. Acta Physiol. Plant. 32, 103-114 https://doi.org/10.1007/s11738-009-0385-1

Tzin V., Galili G. (2010): New insights into the shikimate and aromatic amino acids biosynthesis pathways in plants. Mol. Plant 3, 956-972 https://doi.org/10.1093/mp/ssq048

Valderrama R., Corpas F. J., Carreras A., Gomez-Rodriguez M. V., Chaki M., Pedrajas J. R., Fernandez-Ocana A., Del Rio L. A., Barroso J. B. (2006): The dehydrogenase-mediated recycling of NADPH is a key antioxidant system against salt-induced oxidative stress in olive plants. Plant Cell Environ. 29, 1449-1459 https://doi.org/10.1111/j.1365-3040.2006.01530.x

Wang W. X., Vinocur B., Altman A. (2003): Plant responses to drought, salinity and extreme temperatures: towards genetic engineering for stress tolerance. Planta 218, 1-14 https://doi.org/10.1007/s00425-003-1105-5

Yokthongwattana K., Chrost B., Behrman S., Casper-Lindley C., Melis A. (2001): Photosystem II damage and repair cycle in the green alga Dunaliella salina: Involvement of a chloroplastlocalized HSP70. Plant Cell Physiol. 42, 1389-1397 https://doi.org/10.1093/pcp/pce179

Zhang L., Liu J., Wang X. M., Bi Y. R. (2013): Glucose-6-phosphate dehydrogenase acts as a regulator of cell redox balance in rice suspension cells under salt stress. Plant Growth Regul. 69, 139-148 https://doi.org/10.1007/s10725-012-9757-4

Zhu J. K. (2003): Regulation of ion homeostasis under salt stress. Curr. Opin. Plant Biol. 6, 441-445 https://doi.org/10.1016/S1369-5266(03)00085-2

Received: August 31, 2016

Final version accepted: October 28, 2016

First published online: May 4, 2017 
$S$ up plementary $M$ a terial

\title{
NADP-dependent enzymes are involved in response to salt and hypoosmotic stress in cucumber plants
}

\author{
Veronika Hýsková ${ }^{1}$, Veronika Plisková ${ }^{1}$, Václav Červený ${ }^{2}$ and Helena Ryšlavá ${ }^{1}$
}

1 Department of Biochemistry, Faculty of Science, Charles University, Hlavova 2030, Prague 2, 128 43, Czech Republic

2 Department of Analytical Chemistry, Faculty of Science, Charles University, Hlavova 2030, Prague 2, 128 43, Czech Republic

Supplementary Table S1. Statistical comparison of plants exposed to $100 \mathrm{mM} \mathrm{NaCl}$ (salt) with plants in distilled water (water) and with plants grown in soil (soil)

\begin{tabular}{|c|c|c|c|c|c|c|c|c|c|c|c|c|}
\hline & \multicolumn{12}{|c|}{ Day of stress } \\
\hline & \multicolumn{3}{|c|}{0} & \multicolumn{3}{|c|}{1} & \multicolumn{3}{|c|}{2} & \multicolumn{3}{|c|}{3} \\
\hline & Salt/soil & $\begin{array}{c}\text { Salt/ } \\
\text { water }\end{array}$ & $\begin{array}{c}\text { Water/ } \\
\text { soil }\end{array}$ & Salt/soil & $\begin{array}{c}\text { Salt/ } \\
\text { water }\end{array}$ & $\begin{array}{c}\text { Water/ } \\
\text { soil }\end{array}$ & Salt/soil & $\begin{array}{c}\text { Salt/ } \\
\text { water }\end{array}$ & $\begin{array}{c}\text { Water/ } \\
\text { soil }\end{array}$ & Salt/soil & $\begin{array}{c}\text { Salt/ } \\
\text { water }\end{array}$ & $\begin{array}{c}\text { Water/ } \\
\text { soil }\end{array}$ \\
\hline RWC & $\downarrow_{0.002}$ & $\downarrow_{0.002}$ & N0.905 & $\downarrow 0.002$ & $\downarrow_{0.005}$ & N0.300 & $\downarrow \leq 0.001$ & $\downarrow_{0.002}$ & N0.420 & $\downarrow \leq 0.001$ & $\downarrow_{0} 0.017$ & $\downarrow_{0.004}$ \\
\hline $\mathrm{Na}^{+}$leaf & N0.548 & N0.850 & N0.297 & $\uparrow \leq 0.001$ & $\uparrow \leq 0.001$ & N0.082 & $\uparrow \leq 0.001$ & $\uparrow \leq 0.001$ & N0.469 & \begin{tabular}{|c|}
$\uparrow 0.002$ \\
\end{tabular} & $\uparrow 0.003$ & N0.497 \\
\hline $\mathrm{Na}^{+}$root & $\uparrow 0.001$ & $\uparrow 0.005$ & N0.706 & $\uparrow 0.003$ & $\uparrow 0.007$ & N0.101 & $\uparrow 0.004$ & $\uparrow 0.026$ & N0.132 & $\uparrow \leq 0.001$ & $\uparrow 0.011$ & N0.154 \\
\hline $\mathrm{K}^{+}$leaf & N0.284 & N0.560 & N0.445 & \begin{tabular}{|l|} 
N0.196 \\
\end{tabular} & \begin{tabular}{|l|} 
N0.814 \\
\end{tabular} & N0.200 & N0.347 & \begin{tabular}{|l|} 
N0.041 \\
\end{tabular} & N0.077 & $\downarrow_{0.038}$ & \begin{tabular}{|l|} 
N0.168 \\
\end{tabular} & N0.504 \\
\hline $\mathrm{K}^{+}$root & N0.875 & N0.244 & N0.483 & $\downarrow 0.009$ & N0.194 & N0.833 & $\downarrow \leq 0.001$ & $\downarrow_{0.005}$ & N0.141 & $\downarrow_{0.001}$ & $\downarrow \leq 0.001$ & N0.329 \\
\hline Phenolics & $\uparrow 0.043$ & N0.137 & $\uparrow 0.021$ & $\uparrow 0.036$ & $\uparrow \leq 0.001$ & $\downarrow_{0.038}$ & $\uparrow 0.003$ & N0.475 & $\uparrow 0.001$ & $\uparrow 0.001$ & $\uparrow 0.006$ & N0.064 \\
\hline Flavonoids & $\uparrow 0.031$ & N0.089 & N0.317 & \begin{tabular}{|l|} 
N0.062 \\
\end{tabular} & 个0.042 & N0.725 & $\uparrow 0.002$ & \begin{tabular}{|l|} 
N0.051 \\
\end{tabular} & $\uparrow 0.001$ & \begin{tabular}{|c|}
$\uparrow 0.005$ \\
\end{tabular} & 个0.033 & N0.614 \\
\hline Rubisco & N0.865 & N0.184 & N0.191 & \begin{tabular}{|l|} 
N0.365 \\
\end{tabular} & N0.091 & N0.250 & $\downarrow_{0.023}$ & $\downarrow_{0.004}$ & N0.089 & $\downarrow_{0.005}$ & $\downarrow_{0.003}$ & N0.652 \\
\hline Proteins leaf & N0.132 & N0.705 & $\uparrow 0.003$ & \begin{tabular}{|l|} 
N0.060 \\
\end{tabular} & $\uparrow \leq 0.001$ & $\downarrow_{0.003}$ & $\uparrow_{0.012}$ & 个个0.009 & N0.344 & N0.130 & $\uparrow \leq 0.001$ & $\downarrow \leq 0.001$ \\
\hline Proteins root & N0.148 & N0.072 & N0.409 & \begin{tabular}{|l|} 
N0.218 \\
\end{tabular} & 个0.017 & $\downarrow 0.032$ & N0.108 & \begin{tabular}{|l|} 
N0.791 \\
\end{tabular} & N0.103 & \begin{tabular}{|l|} 
N0.925 \\
\end{tabular} & N0.824 & N0.652 \\
\hline NADP leaf & $\downarrow_{0.035}$ & N0.536 & $\downarrow 0.008$ & $\uparrow 0.017$ & $\uparrow 0.003$ & N0.523 & $\uparrow 0.035$ & $\uparrow 0.006$ & $\downarrow 0.004$ & $\uparrow 0.016$ & $\uparrow 0.015$ & N0.267 \\
\hline NADPH leaf & N0.844 & N0.638 & $\downarrow_{0.017}$ & \begin{tabular}{|l|} 
N0.069 \\
\end{tabular} & \begin{tabular}{|l|} 
N0.209 \\
\end{tabular} & $\downarrow_{0.034}$ & N0.330 & N0.061 & N0.130 & N0.109 & N0.650 & N0.267 \\
\hline NADP root & N0.962 & N0.484 & N0.609 & N0.156 & N0.372 & N0.900 & N0.065 & N0.053 & N0.365 & N0.151 & $\downarrow_{0.026}$ & N0.148 \\
\hline NADPH root & N0.998 & \begin{tabular}{l|} 
N0.099 \\
\end{tabular} & N0.201 & N0.912 & \begin{tabular}{|l|} 
N0.897 \\
\end{tabular} & N0.938 & N0.186 & $\downarrow 0.040$ & $\uparrow 0.018$ & N0.858 & $\downarrow \leq 0.001$ & $\uparrow 0.007$ \\
\hline G6PDH leaf & N0.370 & $\uparrow 0.030$ & $\downarrow 0.029$ & \begin{tabular}{|l|} 
N0.179 \\
\end{tabular} & $\downarrow 0.005$ & $\uparrow 0.022$ & N0.056 & \begin{tabular}{|l|} 
N0.998 \\
\end{tabular} & $\uparrow 0.022$ & $\uparrow 0.002$ & $\downarrow_{0.009}$ & $\uparrow 0.001$ \\
\hline NADP-ICDH leaf & $\downarrow \leq 0.001$ & $\downarrow_{0.009}$ & $\downarrow_{0.013}$ & N0.149 & $\downarrow_{0.004}$ & $\uparrow 0.005$ & N0.271 & $\downarrow_{0.034}$ & $\uparrow 0.044$ & $\uparrow 0.009$ & N0.130 & $\uparrow 0.047$ \\
\hline NADP-ME leaf & $\downarrow_{0.046}$ & N0.681 & & \begin{tabular}{|l|} 
N0.061 \\
\end{tabular} & $\downarrow_{0.006}$ & $\uparrow 0.023$ & N0.087 & N0.126 & N0.456 & $\uparrow 0.002$ & $\downarrow_{0.006}$ & $\uparrow \leq 0.001$ \\
\hline SDH leaf & N0.511 & $\uparrow 0.003$ & $\downarrow 0.002$ & \begin{tabular}{|l|} 
N0.409 \\
\end{tabular} & $\downarrow 0.015$ & $\uparrow 0.030$ & $\downarrow_{0.012}$ & $\downarrow 0.021$ & N0.611 & \begin{tabular}{|l|} 
N0.158 \\
\end{tabular} & $\downarrow_{0.004}$ & $\uparrow 0.001$ \\
\hline NP-GAPDH leaf & $\downarrow 0.002$ & $\downarrow_{0.009}$ & N0.149 & N0.182 & N0.089 & N0.157 & N0.623 & N0.161 & N0.196 & $\uparrow 0.009$ & N0.080 & $\uparrow 0.016$ \\
\hline G6PDH root & $\uparrow 0.003$ & $\uparrow 0.002$ & N0.118 & $\downarrow 0.007$ & $\downarrow_{0.010}$ & N0.346 & $\downarrow \leq 0.001$ & $\downarrow_{0.001}$ & N0.084 & $\downarrow \leq 0.001$ & $\downarrow \leq 0.001$ & $\uparrow 0.001$ \\
\hline NADP-ICDH root & N0.750 & N0.563 & N0.354 & N0.569 & \begin{tabular}{|l|} 
N0.848 \\
\end{tabular} & N0.780 & N0.773 & $\downarrow \downarrow_{0.017}$ & $\uparrow 0.023$ & $\downarrow_{0.003}$ & $\downarrow \leq 0.001$ & $\uparrow 0.003$ \\
\hline NADP-ME root & $\uparrow 0.007$ & N0.233 & $\uparrow 0.022$ & N0.373 & N0.081 & N0.150 & N0.366 & $\downarrow_{0.020}$ & $\uparrow 0.010$ & N0.238 & $\downarrow \leq 0.001$ & $\uparrow \leq 0.001$ \\
\hline SDH root & $\uparrow 0.006$ & N0.079 & $\uparrow 0.037$ & N0.817 & $\downarrow_{0.020}$ & $\uparrow 0.020$ & $\downarrow 0.017$ & $\downarrow_{0.019}$ & N0.327 & $\downarrow_{0.018}$ & $\downarrow_{0.002}$ & $\uparrow 0.007$ \\
\hline Glucose-1-DH leaf & N0.213 & N0.055 & N0.230 & \begin{tabular}{|l|} 
N0.836 \\
\end{tabular} & 个0.021 & $\downarrow 0.008$ & ND & $\mathrm{ND}$ & ND & ND & $\mathrm{ND}$ & $\mathrm{ND}$ \\
\hline Gluconate-2-DH leaf & N0.197 & $\uparrow \leq 0.001$ & $\downarrow_{0.049}$ & N0.610 & N0.269 & N0.863 & ND & ND & ND & ND & ND & ND \\
\hline Ribose-1-DH leaf & \begin{tabular}{|l|} 
\\
$\uparrow 0.004$
\end{tabular} & $\uparrow 0.002$ & N0.631 & $\uparrow \leq 0.001$ & 个0.015 & N0.180 & ND & ND & ND & ND & ND & ND \\
\hline Galactose-1-DH leaf & $\uparrow 0.005$ & $\uparrow 0.005$ & N0.544 & N0.063 & N0.070 & N0.588 & ND & ND & ND & ND & ND & ND \\
\hline Glycerol-2-DH leaf & N0.418 & N0.537 & N0.202 & $\uparrow 0.006$ & $\uparrow \leq 0.001$ & $\downarrow_{0.001}$ & ND & ND & ND & ND & ND & ND \\
\hline Glucose-1-DH root & $\uparrow 0.014$ & $\uparrow 0.031$ & N0.727 & $\downarrow 0.031$ & \begin{tabular}{|l|} 
N0.737 \\
\end{tabular} & $\downarrow 0.018$ & ND & ND & ND & ND & ND & ND \\
\hline Gluconate-2-DH root & $\downarrow_{0.008}$ & $\uparrow 0.010$ & $\downarrow_{0.002}$ & N0.600 & N0.130 & N0.083 & ND & ND & ND & ND & ND & ND \\
\hline Ribose-1-DH root & $\uparrow 0.003$ & $\uparrow 0.004$ & N0.407 & \begin{tabular}{|l|} 
N0.251 \\
\end{tabular} & N0.971 & N0.487 & ND & ND & ND & ND & ND & ND \\
\hline Galactose-1-DH root & $\uparrow 0.032$ & $\uparrow 0.039$ & $\mathrm{~N} 0.713$ & $\downarrow 0.003$ & \begin{tabular}{|l|} 
N0.062 \\
\end{tabular} & N0.092 & ND & ND & ND & ND & ND & ND \\
\hline Glycerol-2-DH root & $\uparrow 0.002$ & $\uparrow 0.004$ & $\uparrow 0.016$ & N0.052 & $\downarrow 0.038$ & $\uparrow 0.016$ & ND & ND & ND & ND & ND & ND \\
\hline
\end{tabular}

Pearson's coefficients, which correspond to data in Fig. 1-10, are presented. Symbols $\uparrow, \downarrow$ and N indicate a decrease, an increase or no change of particular parameter. DH, dehydrogenase; G6PDH, glucose-6-phosphate dehydrogenase; NADP-ICDH, NADP-isocitrate dehydrogenase; NADP-ME, NADP-dependent malic enzyme; NP-GAPDH, non-phosphorylating glyceraldehyde-phosphate dehydrogenase; Rubisco, ribulose-1,5-bisphosphate carboxylase/oxygenase; RWC, relative water content; SDH, shikimate dehydrogenase. ND means not determined. 